Article

\title{
Finding the Missing Link between Corporate Social Responsibility and Firm Competitiveness through Social Capital: A Business Ecosystem Perspective
}

\author{
Jaehun Joo $^{1}$, Mike Tae-In Eom ${ }^{2}$ and Matthew Minsuk Shin ${ }^{3, *}$ \\ 1 Division of Management, College of Business and Economics, Dongguk University-Gyeongju, Gyeongju, \\ Gyeonsangbuk-do 780-714, Korea; givej@dongguk.ac.kr \\ 2 Pamplin School of Business, University of Portland, Portland, OR 97203, USA; eom@up.edu \\ 3 Department of International Trade, College of Commerce and Economics, Konkuk University, \\ Seoul 05029, Korea \\ * Correspondence: shinm@konkuk.ac.kr; Tel.: +82-2-450-3774; Fax: +82-2-446-3615
}

Academic Editor: Marc A. Rosen

Received: 8 March 2017; Accepted: 22 April 2017; Published: 28 April 2017

\begin{abstract}
There are existing studies that successfully show the impact of corporate social responsibility (CSR) on firms' financial performance. However, limited attention is paid to its impact on the business ecosystem. CSR could be seen as an investment for building a sustainable business ecosystem, which enhances the competitiveness of this system's members. In that context, this study apprehends and captures the virtuous cycle of firm competitiveness. On analyzing data from interviews with seven firms, the study offers four propositions identifying the structure of the virtuous cycle linking CSR activities to firm competitiveness through the accumulation of social capital within business ecosystems. Based on those propositions, the study offers new insights into CSR research for academics and strategic planning guidelines for managers that integrate social and economic values for a sustainable business ecosystem and firm competitiveness.
\end{abstract}

Keywords: business ecosystem; qualitative research; CSR; social capital; social value

\section{Introduction}

Many findings on the relationship between corporate social responsibility (CSR) and firm economic performance remain inconclusive [1]. Various issues on research methodology, the scope of CSR, data on economic performance, and sampling and measurement errors have frequently been highlighted as reasons for such inconsistent results [1]. As such, the business ecosystem perspective may contribute to finding the missing link between CSR activities and firm competitiveness.

A business ecosystem is a mutually dependent system interconnected by a loose foundation of various ecosystem members, including buyers, suppliers, competitors, and other stakeholders [2]. This perspective and the stakeholder theory have similarities, since a stakeholder is defined as a member who has an interest, right, or influence, and/or who is influenced by a given business [3]. By this theory, stakeholders' interests must be traded off while one stakeholder's interest is assumed to be the priority at one time and others' at other times [4]. On the other hand, the business ecosystem perspective, based on system theory, assumes that members recognize a shared purpose as an economic community and use a common platform coordinated by keystones or focal firms [5,6].

In this context, CSR can be interpreted as an activity that builds benefits that feed back into the business ecosystem. This concept of viewing CSR as an investment for mutual advantage between the corporation and the society has been suggested by researchers such as Drucker [7] and Lin-Hi [8]. Drucker [7] defined CSR as finding business opportunities from solving social problems. Lin-Hi [8] 
suggested that competitiveness of firms can be attained through being a good partner for the society. As such, CSR activities can be viewed as firms' investment or efforts to build sustainable business ecosystems [9]. However, no studies use business ecosystems' perspectives to analyze the relationship between CSR and firm competitiveness. Lacking a business ecosystem perspective, many studies tend to overlook the role of customer participation in the link between CSR and firm competitiveness.

Therefore, this study analyzes the relationship between CSR and firm competitiveness by introducing the mediating role of social capital. Furthermore, the present study views CSR as an investment in the business ecosystem to improve social value, which then develops social capital in the business ecosystem. The present study proposes a virtuous cycle, starting from CSR and linking social value, social capital, and firm competitiveness. To theoretically support the connections within this cycle, the following research questions are answered:

RQ1: How does CSR develop social capital in the business ecosystem?

$R Q 2:$ How does customer participation facilitate accumulation of social capital in the business ecosystem?

RQ3: Does social capital in the business ecosystem influence firm competitiveness?

To answer these, this study used a case study methodology based on a thorough review of CSR literature and rich qualitative data from in-depth interviews with nine informants from seven firms across several industries. Interview data were analyzed through open coding [10]. Data collected from the in-depth interviews were used to answer the research questions and confirm the proposed virtuous cycle.

\section{Literature Review}

\subsection{Social Capital Formation}

Along with physical, financial, and intellectual capital, social capital is an important resource for firm productivity [8]. Business and management scholars report several conditions for social capital formation. First, one group of scholars views social capital as a set of resources derived from social relations among individuals and organizations in a society [11-13]. Social capital has its foundation in the social structure composed of social, market, and hierarchical relations [10]. For instance, Nahapiet and Ghoshal [12] classified social capital into (1) structural, (2) relational, and (3) cognitive dimensions. From the structural perspective, the network and interactions among participants develop the social capital. In the relational perspective, trust, beliefs, and reciprocity between participants create social capital. From the cognitive perspective, the level of sharing and value within the network determines social capital [12]. Putnam [13] classified social capital into bridging social capital, based on weak tie relationships, and bonding social capital, arising from strong tie relationships. These scholars all argue that social capital accrues when participants share common vision and values within their trust-based relations. Firm reputation is also a source of social capital, which enables the firm to build its reputation. For example, firm reputation is closely related to the relational dimension of social capital because the former helps build trust relationships among partners by reducing opportunistic behavior through reputation of trustworthiness [14].

Second, numerous researchers have focused on social capital creation in the context of organizations. Leana and van Buren III [15] defined the construct of organizational social capital by reflecting on the characteristics of social relations among organizations instead of individuals. As such, organizational social capital is understood mainly in terms of (1) associability (participants' collective goal orientation) and (2) shared trust. A firm (not the individual) is considered an actor in terms of organizational social capital, which is a set of resources that an organization can utilize through relationships between the organization and its members, and between the organization and other organizations or the society [16].

Third, social capital exists over various social stratifications and can be measured and analyzed at various levels [17]. Micro-level social capital focuses on individual relationships among family 
members, neighbors, and society; meso-level social capital places strong emphasis on relationships within communities, organizations, and institutions, while macro-level social capital has its foundation in political environments and organizations at country-level units [17]. Therefore, as the perspective of social capital extends from the micro- to the meso-level, its utility moves from individuals to collective assets [17].

\subsection{CSR and Meso-Level Social Capital in Business Ecosystems}

This study pays close attention to meso-level social capital to validate its claims, as the business ecosystem level corresponds to the meso-level. Most studies on the business ecosystem can be classified into (1) explorative studies on its concept and framework [5,6,18-20]; (2) studies on strategy and analysis methods [2,21-23]; and (3) case studies [24-27]. Moore [5,6] defined a business ecosystem as an economic community formed by various stakeholders. Specifically, a business ecosystem is complex interactions enabling co-evolution through reciprocal cycles of cooperation and competition to support the creation of capabilities for innovation [5]. Lewin [28] explained business ecosystem in terms of interconnectedness as companies are operated within a rich alliance/network of interactions sharing fundamental economic properties and fate, while depending on mutual effectiveness and survival. Furthermore, the definition of business ecosystem is extended to a dynamic and adaptive structure that develops and evolves over time as its internal and external environment changes [29]. In addition, a business ecosystem is defined as a set of different landscapes that features a network of companies. Such landscapes are coupled to each other to create evolution: changes in one landscape have an effect on other landscape [28]. Lastly, Rong et al. [20] conceptualized a business ecosystem as an expanded supply chain of industrial stakeholders, including social organizations such as universities and nonprofit organizations.

Iansiti and Levien [23] suggested productivity, robustness, and niche creation as three main factors for evaluating the health of a business ecosystem, and offered three strategic positions for firms: keystones, physical dominators, and niche players. Most studies on business ecosystems use the perspective of a keystone firm or platform leader to address relationships with other members of the ecosystem $[2,23,25]$. Therefore, the business ecosystem perspective, with its focus on common platforms and relationships among actors (members or stakeholders), is a perfect setting in which to examine meso-level social capital formulations and their relations with CSR. However, no business ecosystem study has hitherto addressed the relationship between CSR and social capital in the business ecosystem.

The stakeholder perspective is addressed to any interrelated groups or individuals towards the achievement of the organization's objectives and also a network of stakeholders [3]. This perspective helps firms clarify CSR motivations and performance [30,31]. Although the stakeholder theory successfully offers a rationale for CSR in large firms, it shows limitations when the subjects are small- and medium-sized enterprises (SMEs). As such, Russo and Perrini [30] investigated social capital as a useful approach in understanding the CSR activities of SMEs. They argue that trust, business reputation, and legitimacy with stakeholders such as suppliers, customers, employees, and local community increase SMEs' motivations to participate in CSR. Sen and Cowley's [31] study on CSR from the perspective of SMEs in Australia also insists that an important motivation for SMEs to engage in CSR lies in the accumulation of social capital, while the stakeholder theory fails to explain the motivation of SMEs participating in CSR. Accumulating social capital through strategic CSR is more effective in securing partnerships with NGOs and other community members than through general philanthropic activities [32]. However, CSR-related studies have not hitherto synthetically analyzed the relationships between CSR and social capital, in particular theme-level social capital [16]. A business ecosystem perspective can thus shed light on successfully identifying the relationship between CSR and social capital because the virtuous cycle from CSR, social value, and to social capital is embedded in the business ecosystem concept. 
The impact of CSR can be enhanced through firm activities closely related to strategies, and CSR is found to have a positive effect on the firm's competitive success and performance [33]. On the other hand, firms with better financial performance are likely to engage in CSR. Therefore, it is difficult to determine the impact of CSR on a firm's economic performance. For example, Rowley and Berman [34] argued that the link between CSR activities and economic performance is not clearly defined. The motivation for firm engagement in CSR is related to the extent of stakeholders' influence on firm performance. For instance, investors, competitors, governments (through policies and regulations), NGOs, and local communities exercising their political and financial influence can motivate firms to engage in CSR activities. This pressure from stakeholders allows a better understanding of the need to analyze CSR at the level of business ecosystems. Therefore, CSR activities and firm performance should be analyzed not only at individual firms' level, but also at the level of business ecosystems. Additionally, not only the economic performance of CSR, which can directly impact firms, but also social value creation, which can foster a sustainable business ecosystem, should be considered as axes of CSR research. Ultimately, a sustainable business ecosystem offers firm competitive advantage through social capital accumulated in the business ecosystem.

\section{Case Analysis and Propositions}

\subsection{Conceptual Analysis Framework}

Firms engage in various activities to improve their competitiveness, that is, their competence and performance in providing sustainable competitive advantage. Firms create economic value through traditional market-based value activities, such as businesses, transactions, and information exchanges. CSR/CSV (creating shared value) creates both social and economic value. However, creating social value through CSR activities can help foster a sustainable business ecosystem, which can then become a source of firm competitiveness. Figure 1 shows our conceptual framework of how a firm's CSR, as a value activity, contributes to its overall competitiveness directly and indirectly through a sustainable business ecosystem with social capital as a moderator. This conceptual framework becomes a systematic guideline for analyzing data collected from in-depth interviews and is used to draw four propositions.

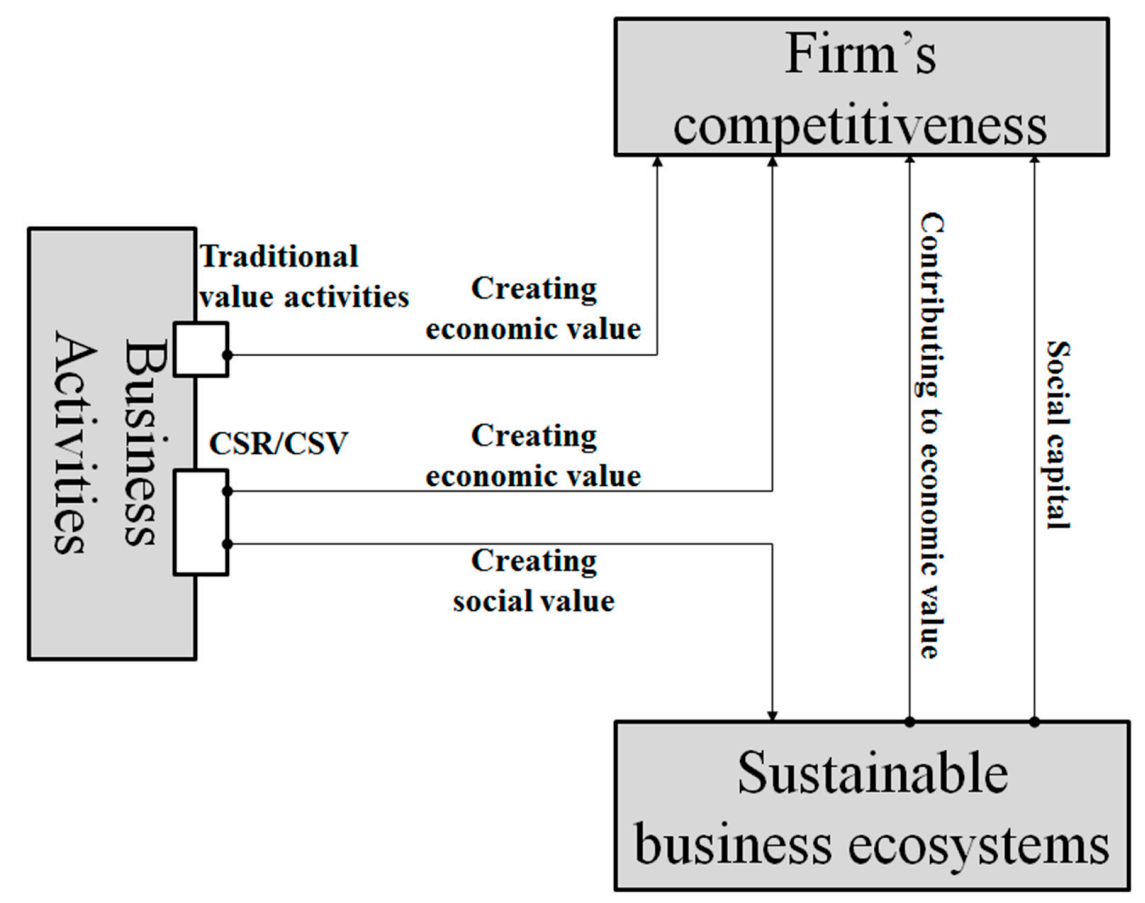

Figure 1. Relationships among business activities, sustainable business ecosystems, and firm competitiveness. 


\subsection{Research Methodology and Data Collection}

Purposive sampling, which is commonly used in qualitative studies, was utilized to select cases and informants. We purposely conducted two different series of interviews in South Korea and the USA to compare the data between a group of firms that are in the initial stages of adopting CSR activities (South Korea) and a group with more seasoned CSR providers (the US). Additionally, snowball sampling was applied by asking an informant to suggest someone else who might be willing or appropriate for the study [35]. Using these sampling methods, we interviewed a total of seven executives from seven firms, including both business-to-business (B2B) and business-to-consumer (B2C) activities. Details on the interviewed executives and firms are organized in Table 1. We believe seven cases are appropriate for inductively developing a theory, as Eisenhardt [36] argues that four to 10 different cases are acceptable as a sample for multiple case studies.

Table 1. Interviews with case firms.

\begin{tabular}{|c|c|c|c|c|}
\hline Case & Overview & $\begin{array}{l}\text { Position } \\
\text { (the Number of } \\
\text { Interviewees) }\end{array}$ & $\begin{array}{l}\text { Interview } \\
\text { Duration } \\
\text { (Minutes) }\end{array}$ & $\begin{array}{l}\text { Transcription } \\
\text { Quantity: A4 Pages } \\
\text { (Word Count) }\end{array}$ \\
\hline SK Planet $(K a)$ & $\begin{array}{l}\text { Provides on and offline and mobile } \\
\text { service platform via its integrated } \\
\text { commerce, digital content, and } \\
\text { advertising and marketing services }\end{array}$ & Manager (1) & 59 & $18(3988)$ \\
\hline LG Uplus Corp. $(\mathrm{Kb})$ & Provides telecommunication services & Team leader (1) & 64 & $22(5229)$ \\
\hline CJ Group $(\mathrm{Kc})$ & $\begin{array}{l}\text { Provides food and food services, bio and } \\
\text { pharmaceuticals, entertainment and } \\
\text { media, and retail and logistics services. }\end{array}$ & $\begin{array}{l}\text { Vice president and } \\
\text { manager }(2)\end{array}$ & 90 & $33(5668)$ \\
\hline $\begin{array}{l}\text { Whole Foods } \\
\text { Market (Ua) }\end{array}$ & $\begin{array}{l}\text { Provides natural and organic food items } \\
\text { through its retail chain }\end{array}$ & Vice president (1) & 63 & $23(6801)$ \\
\hline $\begin{array}{l}\text { Costco Wholesale } \\
\text { Corporation }(\mathrm{Ub})\end{array}$ & $\begin{array}{l}\text { Provides wide selection of merchandise } \\
\text { through a membership-based chain }\end{array}$ & Vice president (1) & 63 & $22(6763)$ \\
\hline Nau $\left(U_{c}\right)$ & $\begin{array}{l}\text { Provides outdoor apparel made of } \\
\text { sustainably sourced materials }\end{array}$ & $\begin{array}{l}\text { Director and } \\
\text { manager }(2)\end{array}$ & 75 & $32(8394)$ \\
\hline $\begin{array}{l}\text { Goodwill Industries } \\
\text { International, Inc. (Ud) }\end{array}$ & $\begin{array}{l}\text { Provides retail services for household } \\
\text { goods collected through donations and } \\
\text { community-based services (job training, } \\
\text { employment placement services, etc.) }\end{array}$ & Director (1) & 80 & $36(10,645)$ \\
\hline
\end{tabular}

$\mathrm{K}$ : South Korea is the region of main operations; U: US is the region of main operations.

Subsequently, three techniques-triangulation, peer debriefing, and member checks-were used for verification [10]. First, triangulation was used to check and establish validation by comparing interview data with other sources such as annual reports, newsletters, webpages, press releases, and documents containing business ecosystems and CSR-related statements [10,37]. Second, three graduate students assisted three researchers through the peer debriefing, which ensured an objective analytical process by working together with disinterested peers [10]. Finally, we asked informants to provide feedback after examining the drafts of our analysis results, and six out of nine informants gave feedback via email or telephone.

The semi-structured interview protocol we used was as follows: "Please tell us members of your business ecosystem or stakeholders", "Please briefly introduce your firm's CSR", "Please share your experience or cases of customer participation in CSR activities", and "What are important factors in building a sustainable business ecosystem?" The last question was followed by more detailed questions such as "How can customers help build such business ecosystems?" These series of questions were purposefully asked to identify whom the interviewees consider as members of their business ecosystem and understand the relationships, platform, and purpose shared by members. Assuming the open/semi-structured interview format, we intentionally started the interview with broad questions, which logically lead to more specific questions. Additionally, we sent the semi-structured interview 
protocol to interviewees prior to the interview, to enhance their understanding of the overall purpose and terms (i.e., business ecosystems, business platform, CSR/CSV) used in the interview.

Interviews were recorded and transcribed verbatim into Korean or English. Table 1 provides an overview of the case firms, and describes the interviews with their representatives. Semi-structured interviews lasting about $8 \mathrm{~h}$ and $24 \mathrm{~min}$ were conducted with nine representatives (186 A4 pages).

Open coding is a technique for systematically analyzing qualitative data [10,37]. In the open coding process, researchers identify concepts through continuous questions and comparative analysis of the raw data.

\subsection{Data Analysis and Propositions}

Firms attempt to create social and improve economic value by implementing CSR. Consequently, CSR activities can be a source of sustainable competitive advantage not only for firms, but also for the business ecosystem. A sustainable business is maintained through the triple bottom line (TBL or 3BL), which focuses on economic, social, and environmental performance measures. In other words, a sustainable business should be socially responsible, environmentally sound, and economically feasible [38]. CSR studies have focused on the direct relationship between CSR performance and firm competitiveness.

The measurement of business ecosystem health [2] focuses on economic value and does not consider the social value of business ecosystems. As such, the sustainability of business ecosystems has to reflect not only economic but also social value, including environmental factors. A sustainable business ecosystem must be productive, robust, innovative, and responsible to all its members as an economic community. The shared purpose of a business ecosystem can be achieved by bringing the collaborative and innovative efforts of all members together and accomplishing more than they could have on their own [39].

When firms plan to implement activities for the sake of the society as a whole, they face a limitation in designing a strategic plan because their society is beyond their manageable scope, and includes ambiguous and uncontrollable domains. However, if the scope is limited to their business ecosystems, firms can design more concrete and feasible strategic plans. Particularly, a firm's social value creation through CSR can occur within the business ecosystem. As such, firms need to decide on their CSR investments by considering members of the business ecosystem. The motivation behind CSR includes efforts to address relationships with business partners, the requirements of consumers and NGOs, avoiding the threat of illegitimacy from the community, and reducing reputational risks [40]. Most investment in CSR activities is associated with members of the business ecosystem. Firms are not willing to plan and implement their CSR projects obscurely, without focused domains or strategic thinking, but rather plan to efficiently invest their limited resources in CSR activities related to members of the business ecosystem. Excerpts from interviews with $\mathrm{Kb}$ (Table 2) represents firms investing in CSR projects with the foundation on their core competence and focusing on CSR activities related to their business domains. The more closely related to the business ecosystem domain a CSR project is, the more helpful it is in building a sustainable business ecosystem. In addition to CSR activities implemented in line with the nature of the business, the firm cares for all members in their business ecosystems through CSR. These assertions are evident for Kc of Table 2. 
Table 2. Key concepts and excerpts from interviews on the relationship between CSR and the business ecosystem.

\begin{tabular}{|c|c|c|c|}
\hline Assertions anc & Key Concepts & Comments & Source \\
\hline \multirow{2}{*}{$\begin{array}{l}\text { Building a sustainable business } \\
\text { ecosystem through CSR activities } \\
\text { in line with the nature of business }\end{array}$} & $\begin{array}{l}\text { CSR in line with the nature of } \\
\text { business }\end{array}$ & $\begin{array}{l}\text { "We contribute to society in areas related to our core businesses. That is, we } \\
\text { develop and provide services that help provide our society with value. In so doing, } \\
\text { we orient sustainable management, through which all members of our business } \\
\text { ecosystem benefit. The most important point is to facilitate and promote CSR } \\
\text { activities in line with the nature of our business." }\end{array}$ & $\mathrm{Kb}$ \\
\hline & CSR caring for all members & $\begin{array}{l}\text { "Why do we focus on CSR and promote CSR-related activities? The reason is we } \\
\text { would like to be socially responsible within the scope of our businesses. While } \\
\text { focusing on our core businesses, we strive to create an ecosystem in which we care } \\
\text { for all stakeholders." }\end{array}$ & $\mathrm{Kc}_{\mathrm{c}}$ \\
\hline $\begin{array}{l}\text { Building markets favorable to the } \\
\text { firm through investment in } \\
\text { CSR activities }\end{array}$ & $\begin{array}{l}\text { Building markets favorable to } \\
\text { its own firm through CSR } \\
\text { activities, running open } \\
\text { innovation center for } \\
\text { educating developers }\end{array}$ & $\begin{array}{l}\text { "We are running a school (called an open innovation center) in which we educate } \\
\text { application developers, architects, designers, and other customers. The purpose of } \\
\text { their education and training is their social contribution by being better and more } \\
\text { knowledgeable. On the other hand, we eventually benefit, as those who finish the } \\
\text { course provide the market with better applications such that we can introduce and } \\
\text { sell better and more innovative products." }\end{array}$ & $\mathrm{Ka}$ \\
\hline \multirow{3}{*}{$\begin{array}{l}\text { Achieving the shared purpose of } \\
\text { the business ecosystem through } \\
\text { investment in CSR activities }\end{array}$} & $\begin{array}{l}\text { Supporting a healthy dietary } \\
\text { life by hiring doctors and } \\
\text { reducing customers' } \\
\text { medical costs }\end{array}$ & $\begin{array}{l}\text { "We have five doctors. They teach you from the health standpoint, like what food } \\
\text { does in your body, what positive nutritional value a certain type of food has versus } \\
\text { those foods that are more destructive. They educate team members on health and } \\
\text { nutrition. Hundreds of team members are on the floor of stores talking about this. } \\
\text { That is a business. We believe that our healthier team members take the burden off } \\
\text { the medical community." }\end{array}$ & \multirow[t]{3}{*}{$\mathrm{Ua}$} \\
\hline & $\begin{array}{l}\text { Organizational socialization } \\
\text { of customers by building } \\
\text { bridges between employees } \\
\text { and customers }\end{array}$ & $\begin{array}{l}\text { "Anyway, it is very hard to teach people to eat right, it is very emotional for people. } \\
\text { So we do our best to not to be preachy about it. But we do believe that our } \\
\text { customers are going to continue learning. We have to build bridges for people, so } \\
\text { that they can see their way to a healthier future." }\end{array}$ & \\
\hline & $\begin{array}{l}\text { A mission to change the } \\
\text { world by investing in } \\
\text { CSR activities }\end{array}$ & $\begin{array}{l}\text { "The expected return from the investment is that people will live longer and shop } \\
\text { longer. This is not a campaign. It is not an advertising campaign. It is a crusade. } \\
\text { Like, we have a heroic mission. We are on a heroic mission to change the world." }\end{array}$ & \\
\hline
\end{tabular}


Ka established the Open Innovation Center (OIC) to create an open mobile ecosystem. The OIC provides training courses for external development firms and individual developers, providing open application programming interfaces (APIs) for Ka, and finally supporting their startups. The OIC is a CSR activity in an area related to the nature of its business, addressing online and mobile service platforms. The investment in OIC reflects an effort to foster a feasible business ecosystem. This activity educates key stakeholders and eventually builds favorable market conditions by investing in innovative and creative CSR activities as described in the interview comments from the executive of Ka in Table 2.

Ua invested USD 25 million in local producers to provide seasonal produce and reduce distribution costs through a local producer loan program (LPLP). Moreover, Ua established the Whole Planet Foundation to implement CSR activities. In addition to investing in suppliers, Ua hired physicians to educate customers on healthy eating, as the Ua executive describes in Table 2. CSR activities for customers and suppliers were an investment for building a sustainable business ecosystem by creating a healthier future through organic food and nutrition. In so doing, a firm can support a higher cause and help members in its business ecosystem to realize their shared purpose.

One way to create social value for customers as a member of the Ua business ecosystem was to support healthy living and reduce medical costs. It is necessary for customers to understand the mission of Ua to build a sustainable business ecosystem. Investment in CSR, including the hiring of doctors, facilitates a better understanding of customers. Even when it is difficult for doctors to educate customers directly, team members educated by doctors and working in stores talk about healthy food and nutrition as indicated in the comments from Ua (Table 2). All of these serve as communication venues through which all business ecosystem members come together and share a common understanding.

This process of understanding reflects the socialization of customers through their orientation toward the shared purpose of the Ua business ecosystem. The LPLP program is an investment in social value creation for suppliers as members of the Ua business ecosystem because small local farmers and artisans need help in making their dreams reality. This investment ultimately contributes to a sustainable business ecosystem. As such, the firm is rarely expected to derive direct economic value from CSR activities, yet the ultimate purpose of investing in CSR activities is closely related to achieving a sustainable business ecosystem through realizing the mission of the business ecosystem.

Table 2 shows assertions and key concepts derived from the interview data by grouping similar concepts into categories. Firms are building a sustainable business ecosystem through CSR activities in line with the nature of the business and markets favorable to the firm. They also realize the shared purpose of the business ecosystem, such as "changing the world." Based on an analysis of data collected from interviews and case firms, the following is proposed.

Proposition 1. Firms have been building markets (or business ecosystems) favorable to them and a sustainable business ecosystem through CSR activities, in line with the nature of business, and have thus been achieving the shared purpose of this business ecosystem (for example, changing the world). Thus, CSR activities have a positive effect on building a sustainable business ecosystem.

Suchman [41] defined "legitimacy" as a generalized perception or assumption that the actions of an organization are desirable, proper, or appropriate within some socially constructed system of norms, values, and beliefs. Firms cannot help but accept institutional pressure and social demands or needs. Corporate social reporting is a means of gaining and reinforcing firm legitimacy and managing reputation [42]. Firms promote their CSR activities through mass or social media to increase their legitimacy. Therefore, CSR is related to social capital because reputation comes from CSR activities via gaining legitimacy.

Sen and Cowley [31] analyzed the motivation behind the CSR activities of SMEs in Australia, finding that they formed trust and accumulated social capital through those activities, thus reducing public monitoring and eliciting support from local communities. Social media accelerates the speed 
and scope of message diffusion for firms. For instance, Eberle, Berens, and $\mathrm{Li}$ [43] argued that messages of CSR activities on the social media have considerable influence on a firm's reputation.

The social capital of a business ecosystem is defined as a set of resources related to trust, reciprocity, and value-sharing based on relational networks among ecosystem, corresponding to meso-level social capital. CSR activities form social capital through social value creation because CSR facilitates interactions and value-sharing among members such as local communities and customers of the business ecosystem, and builds trust among them.

When the worst flood in its history devastated the city of Austin in 1981, Ua's stores were damaged. Customers and neighbors voluntarily joined the staff to repair and clean up the damage. Social capital played an important role in the recovery and reopening of the store only 28 days after the flood [44]. CSR activities help form social capital by facilitating interactions with members of the business ecosystem and reinforcing solidarity with them, although the firm cannot expect direct payoffs from CSR. The first comment from the interview with Ua in Table 3 implies that the cognitive dimension of social capital comes from the sharing of value, mission, and culture with the members of the business ecosystem. The second comment reflects the structural dimension of social capital resulting from solidarity or a deep bond built through CSR activities.

In 2013, Kc established its own CSV management department focusing on integrating business efforts with social and environmental values. Its efforts to build a good relationship with local communities are a good example of social capital from the creation of social values through CSR.

Earning customers' trust through authentic CSR activities is another way of creating social capital from CSV and CSR. Kc's two typical CSVs were sustainable agricultural development in rural Vietnam, to improve the firm's food manufacturing and distribution by enhancing the capability of local Vietnamese farmers, and the Silver Couriers project, which provides senior citizens with opportunities to work and continues to develop effective ways to assist senior citizens in collaboration with related organizations, such as the Korea Labor Force Development Institute for the Aged and the Senior Club. These arguments are supported by comments from the interviews with Kc (see Table 3).

In the worst case, CSV project outcomes reflect social capital because social value is created in the process of solving social issues, and social relations based on frequent interactions and good relationships with members of the business ecosystem are built. This argument is supported by the comments from Kc in Table 3.

Social value can contribute to the formation of social capital. Such social value can be created by supporting other organizations aiming at positive change. For instance, Uc donates $2 \%$ of its revenue to non-profit organizations, such as Change-maker, Ashoka, Ecotrust, and PeopleForBikes, which are working for the environment, people in need, and communities. These organizations do not provide any direct payoff to Uc as members of the Uc business ecosystem. Uc, with headquarters in Portland, Oregon, produces eco-friendly sportswear products that lack the environmental impacts of its competitors. Uc strives to build a sustainable business ecosystem in conjunction with non-profit organizations because it cannot do it alone. Social capital is accumulated in the business ecosystem through trust and the sharing of values activated by regular meetings and interactions based on CSR activities, as outlined by the interview with the executive at Uc in Table 3. 
Table 3. Key concepts and excerpts from interviews on social value creation and the social capital of the business ecosystem.

\begin{tabular}{|c|c|c|c|}
\hline As: & ertions and Key Concepts & Comments & Source \\
\hline \multirow[b]{2}{*}{$\begin{array}{l}\text { No direct payoff but social capital } \\
\text { coming from CSR }\end{array}$} & $\begin{array}{l}\text { A cognitive dimension of social capital coming from } \\
\text { sharing of value, mission, and culture with members of } \\
\text { the business ecosystem. }\end{array}$ & $\begin{array}{l}\text { "I feel my place in this community is to go out and talk about our values and culture, and } \\
\text { make sure that people understand that we are who we say we are. We are not some big } \\
\text { corporation. Today, you are believers, so when I go out, I create believers." }\end{array}$ & \multirow[t]{2}{*}{ Ua } \\
\hline & $\begin{array}{l}\text { A structural dimension of social capital resulting from } \\
\text { some solidarity or deep bond built through CSR activities. }\end{array}$ & $\begin{array}{l}\text { "And if you strive for what is right, then your business prospers. That is just how we believe. } \\
\text { So CSR is just another piece of it like all the other stuff. Look, marine stewardship has no } \\
\text { direct payoff. Whole Planet Foundation has no direct payoff. Healthy Eating has no direct } \\
\text { payoff. But we just believe if you put it all together, we are attracting people who think like } \\
\text { us. And who believe in the same things like us. And because of that there is a deep bond } \\
\text { between us and our community, and we can do more good together." }\end{array}$ & \\
\hline \multirow{3}{*}{$\begin{array}{l}\text { Social capital from the creation of } \\
\text { social value through } C S V^{*} \text { and } C S R\end{array}$} & Creating social value through CSV projects & $\begin{array}{l}\text { "When our new business projects fail, we end up bearing a loss. However, although CSV } \\
\text { projects are not successful, CSV becomes a beneficial business creating social value even if } \\
\text { there is no economic value." }\end{array}$ & \multirow[t]{3}{*}{ Kc } \\
\hline & $\begin{array}{l}\text { Building good relationships with local communities } \\
\text { through CSV projects }\end{array}$ & $\begin{array}{l}\text { "We currently have many business ventures that require a close partnership with local } \\
\text { communities as CSV projects." "It is very important to understand the local community and } \\
\text { create and nurture social networks with key entities within the community, which, in turn, } \\
\text { will lead to close and successful working relationships." }\end{array}$ & \\
\hline & $\begin{array}{l}\text { Accumulating trust and beliefs from customers through } \\
\text { authentic CSR activities }\end{array}$ & $\begin{array}{l}\text { "Firm is also a member of the business ecosystem. So is the customer. When the two meet as } \\
\text { respective members of the ecosystem, the most important factor to bring the two parties } \\
\text { together is to form trust and beliefs. All those are available when customers understand the } \\
\text { authentic CSR of the firm, and they are willing to be part of the company." }\end{array}$ & \\
\hline \multirow[b]{2}{*}{$\begin{array}{l}\text { Forming social capital through social } \\
\text { value creation }\end{array}$} & $\begin{array}{l}\text { Creating social value by supporting other organizations } \\
\text { aiming at a positive change in the world }\end{array}$ & $\begin{array}{l}\text { "We want to help facilitate a positive change in the world. And by us, leading by example by } \\
\text { supporting these organizations to solve humanitarian and environmental issues." }\end{array}$ & \multirow[t]{2}{*}{ Uc } \\
\hline & $\begin{array}{l}\text { Building good relationships with partners through } \\
\text { interactions with them and the sponsorship of events }\end{array}$ & $\begin{array}{l}\text { "We invite those partners to meet with us a couple of times a year to hear about what is } \\
\text { going on in their organizations and keep up with their efforts. So we do like such } \\
\text { interactions with them so that everyone here understands what is going on. We do want that } \\
\text { interaction and we also co-sponsor events from time to time." }\end{array}$ & \\
\hline \multirow{2}{*}{$\begin{array}{l}\text { The social capital of the business } \\
\text { ecosystem coming from reputation } \\
\text { and beliefs based on an } \\
\text { authentic approach. }\end{array}$} & Building long-term relationships with business partners & $\begin{array}{l}\text { "Sometimes we have to work with local farmers in the field, we have to build schools for } \\
\text { their children, and we have to help their supply chain to ensure that they receive fair prices } \\
\text { for their products, so they will stay with us for the long run." }\end{array}$ & \multirow[t]{2}{*}{$\mathrm{Ub}$} \\
\hline & $\begin{array}{l}\text { Building reputation from customers by doing the right } \\
\text { thing and taking a low-key approach }\end{array}$ & $\begin{array}{l}\text { "Because we built a reputation of doing the right thing, doing the right things with our } \\
\text { employees, with members, and with suppliers. And this builds a quite reputation. We do not } \\
\text { advertise that. No billboards. We do not go out in public with those messages. But I think } \\
\text { our customers appreciate that low-key approach and just like what they see." }\end{array}$ & \\
\hline $\begin{array}{l}\text { Social capital coming from beliefs } \\
\text { and the sharing of value with } \\
\text { customers and local communities }\end{array}$ & $\begin{array}{l}\text { Customers' beliefs about the mission of Goodwill doing } \\
\text { the right things }\end{array}$ & $\begin{array}{l}\text { "Customers do not know quite too, but they know that we are up to something good. The } \\
\text { reason why we exist is to do good. They are always top three reasons why people live here. } \\
\text { And it is all about attitudes, shared attitudes of all those customers. Right." }\end{array}$ & $\mathrm{Ud}$ \\
\hline
\end{tabular}

customers and local communities the right things

And it is all about attitudes, shared attitudes of all those customers. Right."

* CSV (Creating shared Value): Policies and operating practices that enhance the competitiveness of a company while simultaneously advancing the economic and social conditions in the communities in which it operates. 
Social capital in the business ecosystem can also be generated through reputation and beliefs based on the firm's efforts to build a long-term relationship with partners and do the right thing. $\mathrm{Ub}$ contributes $1 \%$ of its pre-tax earnings every year, having two main focal areas in its charitable donations: children's health and education. Ub builds its reputation by doing the right thing based on CSR, as well as through long-term relationships with local producers and suppliers. Ub does not promote CSR performance through the mass media, but takes an authentic approach with no frills, as indicated by the interview with $\mathrm{Ub}$ in Table 3. The social capital of the business ecosystem comes from reputation and beliefs, being based on an authentic approach.

Finally, social capital can be a byproduct of sharing values with key members (e.g., customers and local communities) of the firm's business ecosystem. Ud is a typical example of a social enterprise. Its mission is to enhance the dignity and quality of life of individuals and families by strengthening communities, eliminating barriers to opportunities, and helping people in need reach their full potential through learning and the power of work. This mission clearly reflects the shared purpose of the Ud ecosystem. Seeking profits is not Ud's goal, but a means for realizing its mission. Ud customers are either donors, purchasers, or both. The company surveyed the reasons why people donate to Ud every year. According to the interview, the top three reasons are constant every year: the first reason is convenience, the second is keeping the earth green, the last is the belief that Ud is trying to help people. People donate because they believe that Ud creates social value for people in need. Such beliefs and the sharing of values with customers and local communities lead to social capital in the Ud ecosystem, as indicated by the interview in Table 3, which shows the key concepts derived from the interview data by grouping similar concepts into assertions. There is no direct payoff, but social capital comes from the creation of social value through CSR. The social capital of the business ecosystem resulting from reputation and beliefs is based on an authentic approach, as well as the sharing of values with customers and local communities. In this regard, the following proposition is proposed.

Proposition 2. Firms do not expect direct economic performance through CSR activities, but social capital comes from the creation of social value. The social capital of the business ecosystem results from trust based on an authentic approach to CSR and the sharing of values with members of the business ecosystem. Thus, CSR activities enhance social value, which, in turn, increases social capital in the business ecosystem.

Firms facilitate customer participation in business ecosystems by implementing CSR activities in business areas closely related to their core competence. Customer participation in CSR activities stimulates successful CSR performance. In turn, social capital can be formed through frequent interactions between the firm and its customers or local communities and through customers' belief that the firm is doing the right thing. $\mathrm{Kb}^{\prime}$ s providing of telecommunication and Internet services achieved both business and CSR performance by encouraging customers to participate in CSR activities, as commented on in the interview with $\mathrm{Kb}$ (see Table 4).

Customers' participation in CSR activities consistent with their own values is a good source of social capital. Kc established the Nanum (which means "sharing activities" or "benefits" in Korean) Foundation in 2005. The Foundation operates the TalkTalk Housewife Consumer Panel, a program for collecting the opinions of housemakers at the product development stage, and the Donors Camp, an educational support program for poor children to prevent the poverty cycle, as CSR activities. Customers participate in CSR activities because they sympathize with the firm's efforts to do the right thing, as indicated by the interview with Kc (Table 4). 
Table 4. Key concepts and excerpts from interviews on the relationship between customer participation and social capital.

\begin{tabular}{ll}
\hline \multicolumn{2}{c}{ Assertions and Key Concepts } \\
\hline & $\begin{array}{l}\text { Customer participation in a } \\
\text { charitable campaign combined }\end{array}$ \\
$\begin{array}{ll}\text { Understanding the shared purpose } \\
\text { by promoting customer }\end{array}$ & with the business activity \\
participation in CSR activity in & transforming existing billing \\
line with the nature of business & systems into electronic systems \\
& using email
\end{tabular}

"The most important point is to facilitate and promote CSR activities in line with the nature of our business. We have a billing system for more than 10 million customers. This billing system used to be very costly because most invoices were sent by post mail, with only $25 \%$ by email. We wanted to convert the system into an electronic system based on email. Therefore, we implemented this business initiative for a new billing system with a charitable campaign: when a customer converts from a traditional mail based billing system to an email-based

More than $70 \%$ of our existing customers willingly switched to the electronic billing system. We are able to donate around USD 200,000 every year to help children and patients with incurable diseases."

Social capital based on sharing the

Customers' participation in the mission and mutual trust

CSR activities consistent with

their own values

"Our customers who are involved in the TalkTalk Housewife Consumer Panel and Donors stemming from understanding the customer's role by participating in CSR activities

Letting customers feel their roles in contributing to society through their participation "Ormp are participating in the CSR activities of CJ Nanum Foundation because they share values or mission with the CJ Foundation and like these."

"It is important to make our customers feel that they are making positive contributions to society by using our services or partially doing business with our firm."

Social capital stemming from customers who have the pride of being members of the sustainable business ecosystem

Understanding customers' roles and relationships with the firm

"We strongly believe that our customers understand their roles and relationships with our company because they see that payments for products or services go to under-privileged people or are used for a better business ecosystem through us because they pay for business services we provide."

A sense of pride at being an integral part of the ecosystem through customer participation

"Customers have a sense of pride at being an integral part of the ecosystem when they get feedback, suggestions, or insights from us as they participate into our businesses."

"If you look at the lifecycle analysis of a piece of apparel, $40 \%$ of the environmental cost of a product is in its care and maintenance. It is in washing and drying, $40 \%$ of the environmental impact is in apparel care, and only about $5 \%$ in the footwear. If we could do a better job of educating our consumers on the use and care of their product, we would lower the

Beliefs and trust based on Understanding the shared purpose of reducing understanding the shared purpose through customer participation

environmental impacts and the total cost of a product through customer participation environmental impact of the product greatly. Marks \& Spencer did an advertising campaign where they asked consumers to lower the wash temperature of their product by 10 degrees because it uses $40 \%$ less energy. So the impact is huge. It is a very good place for you to look for the impact of a product, because people think that once it leaves our warehouse, we do not own it anymore and it is not our problem. But I believe it is partly our problem and we need to educate the consumer about it." 
Firms also need to make customers feel they are making positive contributions to the sustainability of business ecosystem by participating in CSR activities initiated by firms recognized as members of the business ecosystem, as indicated by the interview with $\mathrm{Kb}$ (Table 4).

From the business ecosystem perspective, customers' purchasing action for a product/service is similar to citizens' casting of votes for politicians. Just like citizens, customers support a firm, which they think will do the right thing and build a sustainable business ecosystem. Customers perceive satisfaction by being vicarious members of the business ecosystem when they see a positive change being made by the firm they support, as indicated by the interview with Ka (Table 4).

Shared beliefs and trust resulting from a clear understanding of the shared purpose through customer participation are also critical to social capital. Generally, customers' purchasing decisions are mainly based on the price of the product (e.g., sporting apparel), not on other factors (e.g., cost related to care, maintenance, and environmental impact). Customers' decisions may be different if they were aware of the total cost of "owning" the product. Therefore, firms should do a better job of educating customers about the product's total ownership cost. The more positively customers are engaged in such educational initiatives (e.g., the environmental impact campaign), the more likely they are to have affinity with it. Customers will then understand the firm's values and the shared purpose of the business ecosystem, and see the authenticity of the firm through long-term campaigns and business practices, which will, in turn, lead to trusting relationships between the firm and customers. A good example of such initiatives is Marks \& Spencer's "Wash at 30 degrees" campaign [45]. As indicated by the interview with Uc (Table 4), Uc informants support the above arguments. Thus, using interview data, we derived the key concepts and assertions concerning the relationship between customer participation and social capital (Table 4): customer participation leads to the formation of social capital in the form of trust and value-sharing through a shared mission, understanding of purpose, and roles and responsibilities. Therefore, we propose the following.

Proposition 3. Customers, as members of the business ecosystem, understand the shared purpose of their participation in CSR activities and take pride in being members of the business ecosystem. Their participation facilitates the accumulation of social capital. Thus, customer participation has a positive effect on the accumulation of social capital in the business ecosystem.

The aforementioned discussion raises the question of how the firm can capitalize on social capital from the business ecosystem to be more competitive. We believe that social capital can help increase firms' competitiveness because social capital is built from shared beliefs and mission, and long-term trust-based relationships with members of the business ecosystem.

Many studies have examined the relationship between social capital and a firm's performance or market value, acknowledging social capital as a critical organizational factor $[11,12,14]$. For example, social capital positively affects firm innovative competence and overall performance [46,47]. It also creates intellectual capital and plays a mediating role in the relationship between open innovation and firm performance [12,47]. Additionally, social capital is known to be a critical antecedent of information, influence, and solidarity, which, in turn, positively affect organizational performance [47].

However, few studies have investigated social capital in terms of the relationships between focal firms and other members of the business ecosystem (e.g., customers, local communities, NGOs, and professional/public association) [24,48]. Olcott and Oliver [48], using in-depth interviews with five firms after a severe earthquake and tsunami in the eastern part of Japan in 2011, identified social capital as a critical enabler, allowing the damaged firms to engage in the rapid mobilization of resources necessary to rebuild and restore their production systems, even under circumstances where there were no pre-contractual agreements or responsibilities for disaster recovery. Such rapid recovery was possible because suppliers and business partners recognized the importance of continuing operations to provide products or services without delays or interruptions and due to the shared consensus about the higher-level goal of keeping Japan's reputation and strategic position in the global supply 
chain. Additionally, industry associations, NGOs, and local communities, as members of the business ecosystem, played a critical role in the rapid disaster recovery effort. Olcott and Oliver [48] reveal that trust and vision sharing based on the ecosystem of local associations, NGOs, and local communities facilitated the rapid disaster recovery. In other words, rich social capital accumulated in a business ecosystem enhances its members' competitiveness.

The case of Chez Panisse (CP) is another good example of a firm's social capital leading to overall competitiveness through social values. The $\mathrm{CP}$ business ecosystem features restaurants, a foundation, customers, local suppliers, corporate partners, wine sellers, and culinary schools (graduates, educators, and artists) [24]. CP started with a clear mission for all of its restaurants and established a non-profit foundation to find solutions to environmental, societal, and healthcare-related problems. CP then invested in projects using school grounds as botanical gardens in collaboration with students, teachers, and community leaders. Participants shared $\mathrm{CP}^{\prime}$ s vision, developed a stronger relationship and identity with $\mathrm{CP}$, and steadily changed their dietary habits. This success led to an expanded network of more and diverse project participants (local bakers, chefs, artists, celebrities, food journalists, and reputable firms). This became a solid foundation for social activities that transformed habits concerning organic food, slow-food, and food items from local farms [24]. Through this process of social change, members of the CP business ecosystem created/developed trust, resulting in valuable social capital, which essentially became CP's strategic weapon and a source of sustainable competitive advantage.

Similarly, we found evidence of social capital derived from trust-based social networks that shared common purpose as a critical antecedent of firm competitive advantage in the extensive interview data (Table 5). For example, Ua created a significant amount of social capital through a series of community-focused initiatives (e.g., microloans to small farmers/vendors), which contributed to the growth of an organic market and led Ua to be more competitive. The shared purpose of Ua, called the "holistic chain" (a "one and whole" happy team of suppliers, customers, shareholders, community, and the environment), was well articulated, clearly understood, and shared by all members in its ecosystem, as described in the comments in Table 5.

In another example, Ud has been known for its mission of "helping people" since 1902, and recently added the e-cycle program, an activity for the ethical refurbishment, recycling, and disposal of electronics, to create social value by solving environmental issues as well as by helping disabled people, as indicated by the interview with Goodwill (Table 5). Trust based on the beliefs of Ud business ecosystem members has been a great conduit, and more people are resonating with Ud's mission and participate through donations. This example also indicates that social capital accumulated in the business ecosystem reverts into firm competitiveness.

Another way of creating social value is to provide people with opportunities to work and be productive. Kc has been effective in creating social value by providing older people and senior citizens in the local community with opportunities to work. In collaboration with local associations and communities, Kc developed its own social network, which has been a good foundation for the firm's competitive advantage, as indicated by the interview with Kc in Table 5. 
Table 5. Key concepts and excerpts from interviews on the relationship between social capital and firm competitiveness.

\begin{tabular}{|c|c|c|c|}
\hline \multicolumn{2}{|c|}{ Assertions and Key Concepts } & Comments & Source \\
\hline \multirow{2}{*}{$\begin{array}{l}\text { Linking social capital } \\
\text { and competitiveness }\end{array}$} & $\begin{array}{l}\text { Growth of the organic market resulting from } \\
\text { efforts to implement a heroic mission } \\
\text { through CSR }\end{array}$ & $\begin{array}{l}\text { "Organic is now } 4 \% \text { of all food consumed, which is incredible. When we started, it was probably } 0.1 \% \text { or } 0.01 \% \text {. So, } \\
\text { it increased thousands of times. But as we grow, that heroic mission that was once organics has continued getting } \\
\text { more aggressive. Whole Foods Market has a foundation that we fund, our customer fund, and Whole Foods } \\
\text { market, } 100 \% \text { of donations from our customers goes to microloans." }\end{array}$ & \multirow[t]{2}{*}{$\mathrm{Ua}$} \\
\hline & $\begin{array}{l}\text { Social capital based on a holistic chain of } \\
\text { relationships with communities through } \\
\text { microloan programs }\end{array}$ & $\begin{array}{l}\text { "I see social capital as a connection, but I talked holistically about how our relationship goes in the circle. We have } \\
\text { to have a holistic chain. We go back to the community that we source in to do the microloans. We go into those } \\
\text { communities that shell out cashews and provide loan money to be able to build stronger business ecosystem in } \\
\text { those communities." }\end{array}$ & \\
\hline \multirow{2}{*}{$\begin{array}{l}\text { Donations based on } \\
\text { people's beliefs }\end{array}$} & $\begin{array}{l}\text { Forming trust by solving environmental } \\
\text { issues by participating in e-cycle programs, } \\
\text { as well as by helping disabled people }\end{array}$ & $\begin{array}{l}\text { "Everything has to be recycled. We are actually the member, one participant of e-cycle in Oregon. Last year, just in } \\
\text { recycling electronics, we recycled more than } 13 \text { million pounds of electronics out of the land field. I really do think } \\
\text { donating is emotional. A lot of people believe there could be place for people with developmental disability and } \\
\text { intellectual disability." }\end{array}$ & \multirow[t]{2}{*}{ Ud } \\
\hline & $\begin{array}{l}\text { Generating sales revenue from } \\
\text { customers' donations }\end{array}$ & $\begin{array}{l}\text { "And just in a new } 44 \text { inch LED TV last Monday ... no last Thursday, we just found was donated to us USD } 1800 \\
\text { bracelet. You know "Huckleberry Finn" with the original author, classic. We sold on shop Goodwill.com, a Frank } \\
\text { Weston Benson, oil painting, he is a master, for USD 465,000." }\end{array}$ & \\
\hline $\begin{array}{l}\text { Social networks as } \\
\text { invaluable assets for } \\
\text { gaining competitive } \\
\text { advantage }\end{array}$ & $\begin{array}{l}\text { Building partnerships and social networks } \\
\text { by employing older and senior citizens and } \\
\text { collaborating with related local associations }\end{array}$ & $\begin{array}{l}\text { "It is very important to understand the local community and create and nurture social networks with key entities } \\
\text { within the community, which, in turn, will lead to close and successful working relationships that benefit both us } \\
\text { and the local community. We strongly believe that such partnerships and social networks will be invaluable assets } \\
\text { for a long-run competitive position for years to come." }\end{array}$ & Kc \\
\hline \multirow[t]{2}{*}{$\begin{array}{l}\text { A competitive } \\
\text { advantage derived } \\
\text { from social capital } \\
\text { spontaneously }\end{array}$} & $\begin{array}{l}\text { Building customer trust through the } \\
\text { following activities: pursuing social } \\
\text { accountability beyond conducting business } \\
\text { ethically and being compliant with relevant } \\
\text { regulations; caring for employees and } \\
\text { building good relationships with suppliers; } \\
\text { consistently executing business practices }\end{array}$ & $\begin{array}{l}\text { "Well, when we started the business } 30 \text { years ago, we did not give any thought to social value or social capital } \\
\text { concepts. It was only to run the business in an ethical fashion, to stick to a code of ethics in how we run the } \\
\text { business. We did not think about the social accountability connection working with economic viability and } \\
\text { competitiveness. What has happened, our experience over } 30 \text { years in the way we run the business has evolved } \\
\text { into competitive advantage because people trust us. They trust us as a business that provides merchandise; they } \\
\text { trust us to stand behind the products we sell. They trust us to take care of the people who work with us, and they } \\
\text { trust us in how we handle our relationships with suppliers. What happened over time by consistent execution of } \\
\text { our practices, we developed this huge trust and that is the connection and that is the competitive advantage that we } \\
\text { enjoy, that people feel good about shopping with us because of the way we run our business over the years." }\end{array}$ & \multirow[t]{2}{*}{$\mathrm{Ub}$} \\
\hline & $\begin{array}{l}\text { Higher economic performance or } \\
\text { competitive advantage resulting from trust, } \\
\text { based on a deep bond with customers }\end{array}$ & $\begin{array}{l}\text { "And that creates a very powerful bond that translates into competitive advantage. Costco averages USD } \\
150 \text { million per store per year in sales. Our competitors have the same products, the same box. They have resources } \\
\text { to buy better than we do. Why they wouldn't be 150? It is that connection, that bond that we have created over } \\
\text { time that has translated into that kind of competitive advantage." }\end{array}$ & \\
\hline
\end{tabular}


Customers' trust toward a firm increases not only when the firm offers great products or services, but also when it shows social responsibility, such as offering employee benefits and maintaining long-term positive relationships with suppliers over time. Customers generally know CSR activities that a firm engages in with the local communities. If a firm engages in CSR activities through business practices over a long period of time, it can develop very important relationships and accumulate customer trust. Although firms do not consciously consider trust as a relational dimension of social capital, their competitive advantage is often derived from unintentional activities related to social capital, as indicated by the interview with $\mathrm{Ub}$ (Table 5).

Table 5 shows key concepts derived from interview data and assertions. In summary, social capital based on social networks as invaluable assets for gaining a competitive advantage is linked to firm competitiveness because the growth of market and benefits (e.g., donations) from members of the business ecosystem is based on trust and shared purpose. In this regard, the following proposition is suggested.

Proposition 4. Social capital accumulated in the business ecosystem through CSR has a positive effect on firm competitiveness because social capital enables the firm to secure resources and knowledge, to mobilize resources, thus allowing rapid recovery from disasters, and to seize opportunities amid market growth. Therefore, social capital of the business ecosystem plays as a mediating between CSR and firm competitiveness.

Four propositions were proposed in this paper. These propositions are based on Tables 2-5, which describe assertions, key concepts, and comments from informants. Assertions and examples of key concepts from each Table are derived from the open coding analysis. For example, two assertions of Table 3 related to Ua and Kc were drawn from the open coding process as shown in Appendix A. Similar concepts were grouped into sub-categories, which were then further classified into categories. A total of 91 concepts were grouped into 26 sub-categories, then to 10 categories through the aggregation and renaming processes. Finally, we presented five assertions to propose Proposition 2. In general, sampling of qualitative research continues until theoretical saturation is reached. Theoretical saturation means that additional new concepts are not found from further data collection [10,37]. In this study, we identified that no more new concepts could be found from sampling.

Finally, our extensive interview data collected from the US and South Korea revealed interesting yet idiosyncratic differences in how CSR leads to firm competitiveness between the two countries' business environments (see Table 6). CSR in the US is well aligned with the firms' core businesses [49], whereas Korean firms move slowly from handling CSR and core businesses separately (CSR for building corporate reputation and overcoming anti-business sentiment and/or negative attitudes) to integrating the two, as in the US. Many firms in South Korea have been offering CSV in the transformational stage since 2012. For example, Kc established a CSV management division, responsible for social contributions and sustainable management, in 2013. 
Table 6. Different characteristics between the US and Korea.

\begin{tabular}{|c|c|c|c|}
\hline & Excerpts from Interviews & Difference between U.S. and Korea Cases & $\begin{array}{c}\text { Relations with Firm } \\
\text { Competitiveness }\end{array}$ \\
\hline US cases & $\begin{array}{l}\text { "We are about helping people with barriers, the planet, your pocketbook. That's the only reason why we are here is } \\
\text { to impact on the deepest and best route the communities we serve." } \\
\text { "And our core values are direct statements about the relationships with our stakeholders." } \\
\text { "It is a crusade. Like, we have a heroic mission. We are on a heroic mission to change the world." } \\
\text { "We really believe that health and well-being of our planet is really dependent on for profit businesses really } \\
\text { supporting non-profit organizations that are working to create positive change. Fundamentally, we want to help } \\
\text { facilitate the positive change in the world. And by us, you know, we are leading by example, by supporting these } \\
\text { organizations working for humanitarian issues and environmental issues. We are really leading by example and } \\
\text { showing other people that living business world, being profitable company, and supporting organizations that are } \\
\text { making positive changes, can coexist together." }\end{array}$ & $\begin{array}{l}\text { Common characteristics in US cases are as follows: } \\
\text { - CSR such as serving for communities, solving } \\
\text { humanitarian issues and environmental issues } \\
\text { is well aligned with the core businesses; } \\
\text { CSR is considered as the firm's mission to } \\
\text { change the world toward a positive direction. }\end{array}$ & $\begin{array}{l}\text { CSR had already rooted in } \\
\text { case firms as an alternative } \\
\text { for building sustainable } \\
\text { business ecosystems and a } \\
\text { source of competitiveness. }\end{array}$ \\
\hline Korean cases & $\begin{array}{l}\text { "Firms in Korea perform corporate social responsibility activities as a tool to promote themselves. So, those firms } \\
\text { are not genuine when it comes to their CSR activities. They lack authenticity. Firms in Korea actually do not } \\
\text { understand the how and why of CSR." } \\
\text { "If a firm has both 'Marketing and Promotion (M\&P)' and 'Government Relations (GR)' departments operating } \\
\text { together, the functions of M\&P usually die out. GR gets more attention. It is structurally like that. Likewise, if the } \\
\text { M\&P department has both media relations and CSR functions, CSR eventually dies out. Who would maintain the } \\
\text { original intention and execute CSR activities? After all, the major function of M\&P is to maintain firm's positive } \\
\text { media exposures." } \\
\text { "We, as employees, can easily feel that the CEO (or the owner of the firm) has strong convictions toward CSR."” } \\
\text { "And in today's business environment, firms cannot help but view it in the business sustainability perspective. } \\
\text { Investors view it. As of now, we have not encountered any problems as we are just doing it in our own ways } \\
\text { amongst ourselves. However, we must reevaluate the process in order for us to grow as a global company and } \\
\text { maintain our business sustainability." } \\
\text { "It had always been us, the CSR team, who initiate conversations with other business groups and persuade them to } \\
\text { participate in CSR-related activities. It is not easy. So, we simply present the CSR activities. During the } \\
\text { presentations, we focus on convincing the business group leaders. We have come a long way now and such } \\
\text { activities have made big differences. Now, we have a consulting relationship and a collaborative system. That is } \\
\text { where we are today." } \\
\text { "There has to be a support from the government for firms to voluntarily involve in CSR activities. The government } \\
\text { should offer institutional financial support on the basis of laws and regulations. At the same time, the government } \\
\text { must not control voluntary firm CSR activities. The government should be a proactive and dependable stage-setter } \\
\text { and supporter, not an obstacle." }\end{array}$ & $\begin{array}{l}\text { Common characteristics in Korea are as follows: } \\
\text { - Firms are about to recognize CSR in the } \\
\text { perspective of sustainable management from } \\
\text { the view limited to social contributions; } \\
\text { - Firms are preparing an independent } \\
\text { department dedicated to CSR instead of } \\
\text { promoting the department previously in } \\
\text { charge of CSR activities; } \\
\text { CSR activities are strictly associated with } \\
\text { CEO intentions; } \\
\text { - Firms have higher expectation to } \\
\text { governmental roles of providing } \\
\text { law/regulations and } \\
\text { institutional infrastructure. }\end{array}$ & $\begin{array}{l}\text { CSR used to be viewed as an } \\
\text { approach to build corporate } \\
\text { reputation and to overcome } \\
\text { anti-business sentiment } \\
\text { aiming at eliminating a } \\
\text { negative image in the } \\
\text { business ecosystem. This } \\
\text { notion is transforming to CSR } \\
\text { as an approach for gaining } \\
\text { competitiveness by } \\
\text { integrating core businesses } \\
\text { and CSR projects and for } \\
\text { building a sustainable } \\
\text { business ecosystem. More } \\
\text { recently, the Korean firms } \\
\text { focus on CSV. }\end{array}$ \\
\hline
\end{tabular}




\section{Discussion}

This study addressed the question of how firms can achieve a virtuous cycle of investment in CSR, social value creation, social capital accumulation, and firm competitiveness. It posited four propositions on the identification of the structure of the virtuous cycle linking CSR activities to firm competitiveness through the social capital of the business ecosystem.

Propositions 1 and 2 offer an answer to the first research question. Proposition 1 suggests that CSR activities are an important investment in building a sustainable business ecosystem. From the perspective of the business ecosystem, return on investment in CSR activities refers to ecosystem system health [23] and social capital accumulation, as well as existing CSR performance. CSR activities have a positive effect on business ecosystem health. Moreover, social value creation through CSR activities contributes to forming relational, cognitive, structural dimensions of social capital in the business ecosystem. Social capital stemming from CSR activities can increase the survival rate of ecosystem members after an external shock as a measure of business ecosystem robustness.

Proposition 3 is related to the second research question. Social capital formation in the business ecosystem is also facilitated by customer participation into CSR activities. Therefore, the participation of customers as members of the business ecosystem is a promising business practice for accumulating social capital in the business ecosystem. The more customers feel that a CSR activity is consistent with his or her value, the more likely he or she is to proactively participate in the CSR activity so as to gain the shared purpose of the business ecosystem. As customers understand well the shared purpose through their participation in CSR activities and form a better relationship with the firm, their participation facilitates the accumulation of cognitive and relational social capital.

Proposition 4 answers the third research question. Firms create social value through CSR activities. Such activities eventually enrich their business ecosystems by accumulating social capital, and their ecosystems finally create positive effects on their competitiveness through social capital. Most interviewees did not expect the direct economic benefits of CSR activities as indicated in their comments. However, they implicitly recognized the indirect reverting paths from CSR to social value and from social capital to firm competitiveness. Therefore, we argue that social capital in the business ecosystem plays the role of a mediator in the virtuous cycle among CSR, the sustainable business ecosystem, and firm competitiveness (see Figure 1). This proposition is also supported by the tsunami case of Japan [48].

Finally, the CSR orientations of firms are positioned to the continuum of the responsiveness to societal demands and the achievement of a shared purpose. CSR orientation varies according to the shared purpose mode in the business ecosystem. For US firms ( $U a, U b, U c$, and $U d$ ), their shared purposes are relatively concrete and face higher consensus among members of their business ecosystems rather than three cases of South Korea (Ka, Kb, and $\mathrm{Kc}$ ). For example, the informant of Ua said that they have been pursuing social change by realizing a holistic mission of organic foods. Members of the Ua business ecosystem, including suppliers and local communities, have regular meetings and discuss their common objectives. On the other hand, the CSR activities of firms in South Korea focused on the responsiveness to societal demands or consistency of core business routines. As an example of responsiveness to societal demands, CSR activities aim to cover the loss of firm image or reputation resulted from such issue as unfair contractor-to-subcontractor abusive relationships (called Gap-Eul relationships) in South Korea. CSVs from Kb and Kc correspond to the consistency of CSR activities and core business routines [49].

\section{Conclusions}

This study offers a foundation that integrates firms' economic roles based on market relationships and social roles based on social relationships by analyzing the connection among CSR, social value, and firm competitiveness through social capital from the perspective of business ecosystems. The results have some important theoretical implications. First, the study expands the scope of business ecosystem research, which is not limited to participating firms as members of business 
ecosystems, by including customers, NGOs, associations, and communities in the business ecosystem, as units of analysis. Second, the study offers an explanation at the business ecosystem level on the relationship between CSR and firm performance by integrating the mixed results produced by previous studies. These previous studies have focused only on the direct relationship between CSR and firm performance and have not considered indirect reverting paths from CSR to social value and from social capital to firm competitiveness. Third, although previous studies have viewed social capital from individual, organizational, and state perspectives, this study has a business ecosystem perspective, extending the application and practice of social capital. Previous studies have viewed social capital within the relationship among firms in the context of market-based economic relationships. In other words, they have focused only on social capital derived from a relation network of firms in terms of relationship-specific assets [50]. Finally, the propositions developed in this study can be used as hypotheses in future empirical studies on CSR and social capital from the perspective of business ecosystems.

The results have some important practical applications. First, managers can use the results as guidelines for strategic planning by understanding the virtuous cycle between a sustainable business ecosystem supported by social capital and firm competitiveness. Although managers may be implicitly aware of the role of social capital in the relationship between a sustainable business ecosystem and firm competitiveness, they may not consciously invest in CSR activities directly to create social capital. In this regard, by explicitly representing the cyclical relationship, the results provide managers with guidelines for better managerial decision making.

Second, the business ecosystem lens extends the strategic scope of sustainable management by viewing CSR/CSV and other sustainable management activities as an integrated approach to create both social and economic value, and as an investment to build a sustainable business ecosystem.

Finally, although CSR performance can positively impact firm performance, and the market is likely to reward the firm for doing something good [1], firms face daily budget limitations. In this regard, managers with a business ecosystem lens can more clearly define the scope of effects from investing in CSR activities and better view the role of social capital mediating CSR activities and firm competitiveness, as well as the direct link between CSR performance and financial performance.

We propose four propositions explaining the relationships among CSR activities, social value, social capital, and firm competitiveness from the perspective of business ecosystems through a qualitative methodology. While we have shown that the propositions are logically valid through the qualitative analysis of the interviews, the propositions were not tested by using quantitative data. For future research directions, we suggest researchers to consider conducting a quantitative research such as a structural equation modelling method to validate the relationships between constructs (or categories) of each proposition as well as those among the propositions.

Acknowledgments: All sources of funding of the study should be disclosed. Please clearly indicate grants that you have received in support of your research work. Clearly state if you received funds for covering the costs to publish in open access.

Author Contributions: Jaehun Joo and Matthew Minsuk Shin conceived and conducted the interviews; Jaehun Joo, Matthew Minsuk Shin and Mike Eom analyzed the data; Mike Eom contributed the analysis tools; Jaehun Joo, Mike Eom and Matthew Minsuk Shin wrote the paper.

Conflicts of Interest: The authors declare no conflicts of interest. 
Appendix A Example of Open Coding for Table 3

Table A1. Open Coding Process.

\begin{tabular}{|c|c|c|c|}
\hline Assertions & Categories (10) & Sub-Categories (26) & Concepts (91) \\
\hline \multirow{4}{*}{$\begin{array}{l}\text { No direct payoff but } \\
\text { social capital coming } \\
\text { from CSR }\end{array}$} & \multirow[b]{2}{*}{ No direct payoff from CSRs } & No expecting economic benefits & No economic benefits from marine stewardship; no direct payoff from Planet Foundation \\
\hline & & Doing various CSR activities & $\begin{array}{l}\text { Caring about communities and environments; cultivating the next generation of new } \\
\text { products; customers' donation for microloan; Fund for fighting poverty }\end{array}$ \\
\hline & \multirow[b]{2}{*}{$\begin{array}{l}\text { Forming social capital } \\
\text { coming from CSR }\end{array}$} & $\begin{array}{l}\text { Forming a cognitive dimension of } \\
\text { social capital }\end{array}$ & $\begin{array}{l}\text { Going out and talk about our values and culture; making people understand; } \\
\text { understanding vender's perspective; sharing of value, mission, and culture with members; } \\
\text { core values reflecting the relationships with partners }\end{array}$ \\
\hline & & $\begin{array}{l}\text { Forming a relational dimension of } \\
\text { social capital }\end{array}$ & $\begin{array}{l}\text { Creating believers; building Solidarity or deep bond through CSR activities; doing right } \\
\text { things; attracting people; deep bond between us and our community; good together; long } \\
\text { relationships with the brand based on values; LPLP * for creating win-win relationship; } \\
\text { explicit relationship creating harmony; relationship benefiting mutually; doing things } \\
\text { mutually beneficial }\end{array}$ \\
\hline \multirow{5}{*}{$\begin{array}{l}\text { Social capital from the } \\
\text { creation of social } \\
\text { value through CSV } \\
\text { and CSR }\end{array}$} & \multirow[b]{2}{*}{$\begin{array}{l}\text { Creation of social value } \\
\text { through CSV }\end{array}$} & Creating social value through CSV projects & New business project; creation of social value; sustainable agricultural development \\
\hline & & $\begin{array}{l}\text { Building good relationships with local } \\
\text { communities through CSV projects }\end{array}$ & $\begin{array}{l}\text { Local Vietnamese farmers; networks of local communities; close partnership with local } \\
\text { networks; successful working relationships }\end{array}$ \\
\hline & Social value through CSR & Helping senior citizen through CSR & Aged and Senior Clubs; assisting senior citizens \\
\hline & \multirow{2}{*}{$\begin{array}{l}\text { Forming Social capital from } \\
\text { authentic CSRs }\end{array}$} & Accumulating trust and beliefs & $\begin{array}{l}\text { Customers as a member of business ecosystem; forming trust and beliefs; relationships } \\
\text { between parties }\end{array}$ \\
\hline & & Doing authentic CSR & Activities as a corporate citizen; trust from authentic practices; long-term relations \\
\hline
\end{tabular}

* LPLP (Local Producer Loan Program): Whole Food' low-interest loans to help local producers flourish. 


\section{References}

1. Orlitzky, M.; Schmidt, F.L.; Rynes, S.L. Corporate social and financial performance: A meta-analysis. Organ. Stud. 2003, 24, 403-441. [CrossRef]

2. Iansiti, M.; Levien, R. The New Operational Dynamics of Business Ecosystems: Implications for Policy, Operations, and Technology Strategy; Working Paper No. 03-030; Harvard Business School: Boston, MA, USA, 2002.

3. Bryson, J.M. What to do when stakeholders matter: Stakeholder identification and analysis techniques. Public Manag. Rev. 2004, 6, 21-53. [CrossRef]

4. Springman, J. Implementing a Stakeholder Strategy. Available online: https://hbr.org/2011/07/ implementing-a-stakeholder-str (accessed on 7 February 2017).

5. Moore, J.F. Predators and prey: A new ecology of competition. Harv. Bus. Rev. 1993, 71, 75-86. [PubMed]

6. Moore, J.F. Death of Competition: Leadership and Strategy in the Age of Business Ecosystems; Harper Business: New York, NY, USA, 1996.

7. Drucker, P.F. Converting social problems into business opportunities: The new meaning of corporate social responsibility. Calif. Manag. Rev. 1984, 26, 53-63. [CrossRef]

8. Lin-Hi, N. Corporate Social Responsibility: An Investment in Social Cooperation for Mutual Advantage; Discussion Paper No. 2008-6; Wittenberg Centre for Global Ethics: Wittenberg, Germany, 2008.

9. Rogers, S.H.; Gardner, K.H.; Carlson, C.H. Social capital and walkability as social aspects of sustainability. Sustainability 2013, 5, 3473-3483. [CrossRef]

10. Creswell, J.W. Qualitative Inquiry and Research Design: Choosing among Five Traditions; Sage: Thousand Oaks, CA, USA, 1998.

11. Adler, P.S.; Kwon, S. Social capital: Prospects for a new concept. Acad. Manag. Rev. 2002, 27, 17-40.

12. Nahapiet, J.; Ghoshal, S. Social capital, intellectual capital, and organizational advantage. Acad. Manag. Rev. 2011, 23, 242-266.

13. Putnam, R.D. Bowling Alone: The Collapse and Revival of American Community; Simon and Schuster: New York, NY, USA, 2000.

14. Tsai, W.; Ghoshal, S. Social capital and value creation: The role of intrafirm networks. Acad. Manag. J. 1998, 41, 464-476. [CrossRef]

15. Leana, C.R.; van Buren, H.J., III. Organizational social capital and employment practices. Acad. Manag. Rev. 1999, 24, 538-555.

16. Pennings, J.M.; Lee, K. Social capital of organization: Conceptualization, level of analysis and performance implications. In Corporate Social Capital and Liability; Leenders, R., Gabbay, S.M., Eds.; Kluwer Academic Publishers: New York, NY, USA, 1999; pp. 43-67.

17. Bhandari, H.; Yasunobu, K. What is social capital? A comprehensive review of the concept. Asian J. Soc. Sci. 2009, 37, 480-510. [CrossRef]

18. Koenig, G. Business ecosystems revisited. Management 2012, 15, 208-224.

19. Peltoniemi, M.; Vuori, E. Business ecosystem as a new approach to complex adaptive business environments. Proc. eBus. Res. Forum 2004, 20, 267-281.

20. Rong, K.; Hu, G.; Lin, Y.; Shi, Y.; Guo, L. Understanding business ecosystem using a 6C framework in Internet-of-Things-based sectors. Int. J. Prod. Econ. 2015, 159, 41-55. [CrossRef]

21. Adner, R.; Kapoor, R. Value creation in innovation ecosystems: How the structure of technological interdependence affects firm performance in new technology generations. Strateg. Manag. J. 2010, 31, 306-333. [CrossRef]

22. Adomavicius, G.; Bockstedt, J.; Gupta, A.; Kauffman, R. Understanding evolution in technology ecosystems. Commun. ACM 2008, 51, 117-122. [CrossRef]

23. Iansiti, M.; Levien, R. Strategy as ecology. Harv. Bus. Rev. 2004, 82, 68-81. [PubMed]

24. Chesbrough, H.; Kim, S.; Agogino, A. Chez Panisse: Building an open innovation ecosystem. Calif. Manag. Rev. 2014, 56, 144-171. [CrossRef]

25. Cusumano, M. The evolution of platform thinking. Commun. ACM 2010, 53, 32-34. [CrossRef]

26. Isckia, T.; Lescop, D. Open innovation within business ecosystems: A tale from Amazon.Com. Commun. Strateg. 2009, 1, 37-54.

27. Wnuk, K.; Runeson, P.; Lantz, M.; Weijden, O. Bridges and barriers to hardware-dependent software ecosystem participation: A case study. Inf. Softw. Technol. 2014, 56, 1493-1507. [CrossRef] 
28. Lewin, R. Complexity: Life at the Edge of Chaos; The University of Chicago Press: Chicago, IL, USA, 1999.

29. Peltoniemi, M. Preliminary theoretical framework for the study of business ecosystems. Emerg. Complex. Org. 2006, 8, 10.

30. Russo, A.; Perrini, F. Investigating stakeholder theory and social capital: CSR in large firms and SMEs. J. Bus. Ethics 2010, 91, 207-221. [CrossRef]

31. Sen, S.; Cowley, J. The relevance of stakeholder theory and social capital theory in the context of CSR in SMEs. J. Bus. Ethics 2013, 118, 413-427. [CrossRef]

32. Jamali, D.; Yianni, M.; Abdallah, H. Strategic partnerships, social capital and innovation: Accounting for social alliance innovation. Bus. Ethics 2011, 20, 375-391. [CrossRef]

33. Gallardo-Vazquez, D.; Sanchez-Hernandez, M.I. Measuring corporate social responsibility for competitive success at a regional level. J. Clean. Prod. 2014, 72, 14-22. [CrossRef]

34. Rowley, T.; Berman, S. A brand new brand of corporate social performance. Bus. Soc. 2000, 39, $397-418$. [CrossRef]

35. Biernacki, P.; Waldore, D. Snowball sampling problems and techniques of chain referral sampling. Sociol. Methodol. Res. 1981, 10, 141-163.

36. Eisenhardt, K.M. Better stories and better constructs: The case for rigor and comparative logic. Acad. Manag. Rev. 1991, 16, 620-627.

37. Joo, J.; Kim, L. Strategic guidelines for the diffusion of smart grid technologies through a Korean testbed. Inf. Technol. Dev. 2016, 22, 503-524. [CrossRef]

38. Elkington, J. Cannibals with Forks: The Triple Bottom Line of 21st Century Business; Capstone Publishing: Oxford, UK, 1997.

39. Moore, J.F. Shared Purpose: A Thousand Business Ecosystems, a Worldwide Connected Community, and Future. Available online: https://www.arm.com/files/pdf/Shared_Purpose.pdf (accessed on 27 April 2017).

40. Fombrun, C.J.; Gardberg, N.A.; Barnett, M.L. Opportunity platforms and safety nets: Corporate citizenship and reputational risk. Bus. Soc. Rev. 2000, 105, 85-106. [CrossRef]

41. Suchman, M.C. Managing legitimacy: Strategic and institutional approaches. Acad. Manag. Rev. 1995, 20, 571-610.

42. Clarke, J.; Gibson-Sweet, M. The use of corporate social disclosures in the management of reputation and legitimacy: A cross-sectorial analysis of UK Top 100 Companies. Bus. Ethics 1999, 8, 5-13. [CrossRef]

43. Eberle, D.; Berens, G.; Li, T. The impact of interactive corporate social responsibility communication on corporate reputation. J. Bus. Ethics 2013, 118, 731-746. [CrossRef]

44. Mackey, J.; Sisodia, R. Conscious Capitalism: Liberating the Heroic Spirit of Business; Harvard Business Review Press: Boston, MA, USA, 2013.

45. Bell, D.E.; Sanghavi, N.; Winig, L. Marks and Spencer: Plan A. Harvard Bus. Sch. Case Stud. 2009, January, 1-23.

46. Moran, P. Structural vs. relational embeddedness: Social capital and managerial performance. Strateg. Manag. J. 2005, 26, 1129-1151. [CrossRef]

47. Rass, M.; Dumbach, M.; Danzinger, F.; Bullinger, A.C.; Moeslein, K.M. Open innovation and firm performance: The mediating role of social capital. Creativity Innov. Manag. 2013, 22, 177-194. [CrossRef]

48. Olcott, G.; Oliver, N. Social capital, sensemaking, and recovery: Japanese companies and the 2011 earthquake. Calif. Manag. Rev. 2014, 56, 5-22. [CrossRef]

49. Yuan, W.; Bao, Y.; Verbeke, A. Integrating CSR initiatives in business: An organizing framework. J. Bus. Ethics 2011, 101, 75-92. [CrossRef]

50. Chang, K.; Gotcher, D.F. The role of relationship-specific investments in improving performance: Multiple mediating effects of opportunism and cooperation. J. World Bus. 2007, 42, 477-488. [CrossRef]

(C) 2017 by the authors. Licensee MDPI, Basel, Switzerland. This article is an open access article distributed under the terms and conditions of the Creative Commons Attribution (CC BY) license (http:/ / creativecommons.org/licenses/by/4.0/). 